NEW LITERARIA-

An International Journal of Interdisciplinary Studies in Humanities

Volume 2, No. 1, January-February, 2021, PP. 21-28

ISSN: 2582-7375

DOI: https://dx.doi.org/10.48189/nl.2021.v02i1.003

www.newliteraria.com

\title{
From Guerrilla Fighter to National Icon: Revisiting the Political Life of Yasser Arafat
}

\author{
P Boopathi
}

\begin{abstract}
This paper, by looking at various Arab-Israeli conflicts and the resultant loss of homeland for Palestinians in the mid of twentieth century, will analyze how Yasser Arafat grew from guerrilla fighter to the precedent of PNA. By reading through the modern history of Palestine and the articles and books on different conflicts in the second half of twentieth century, the paper will discuss how such a figure was institutionalized in the history of Palestinian national movements. It will also be evaluating the question whether Arafat created Palestinian revolution, or Palestinian revolution created Arafat. The answer to this question, in my opinion, will bring in the contribution of Arafat to the liberation of Palestine. In fact, such a discussion deserves a greater significance, as he is dismissed by some people as terrorist and hailed by others as the revolutionary leader. On the other hand, the ideological shift in his approach to the Palestinian question from "one state solution" to "two state solution" also invites critical intervention as that of the previous one to understand his emphasis on peace negotiations with Israel. Thus, this paper, on the one side, by looking at his development from freedom fighter to the precedent of PNA, will critically analyze the iconizing of his personality as the cult figure in Palestinian national movements. On the other side, it will discuss his ideological positions in Palestinian issue and the two ideological strands of his activism by people and countries throughout the world to the effect of better deducing him as the hero of Palestinian resistance movements.
\end{abstract}

Keywords: Israel-Palestine conflicts, Arafat and the birth of Palestinian revolution, Arafat and PLO leadership, Arafat's ideological shift, the Oslo Accord and Arafat's misfortune, Two Intifadas.

Yasser Arafat (1929-2004), a renowned revolutionary leader of Palestinian National Movements, gained a prominent place in the modern history of Palestine. Despite having been born in Cairo and influenced by "Arab Nationalism," he resolved to fight for beleaguered Palestinians who lost their homeland in the 1948 Israel-Palestine conflict and their right to self-determination. The exiling of thousands of Palestinians as refugees and occupying their places by the Israeli army afflicted him to a large extent of forming a guerilla force "Fatah" in 1959 to combat the Jewish forces. With the founding of Fatah (guerrilla faction), Arafat opened a new chapter in Palestinian activism and changed the course of existing resistance movements. His wide-spread popularity owing to guerrilla strikes and infiltration got him presidential position in Palestine Liberation Organization (PLO), a sole body of Palestinian national movements in 1967. He held this post till his death in 2004, diplomatically managing those unforgettable turmoil years in the history of Palestine and narrowly escaping the murderous attacks more than twice by the Israeli force. In spite of such 
turbulent times, Arafat unflinchingly worked for Palestinian cause and united the fragmented forces under the singular organization of PLO. This he could successfully continue till the 1990s, as Hamas and other organizations had disagreement with Arafat for having signed the Oslo Accord and his peace negotiations with Israel.

This paper, by looking at the evolvement of Arafat from guerrilla fighter to Palestinian president, attempts to discuss the institutionalization of his figure in the Palestinian national Movements. By reading through his various interviews, articles and books written on various conflicts between Arab and Israeli forces in the second half of twentieth century, the paper explicates Arafat's indomitable presence and his resolute leadership in Palestinian Resistance Movements. Further, it seeks to unearth the foundation of resistance movements in Palestine by asking the question "Whether Arafat created Palestinian revolution, or Palestinian revolution created Arafat." By having this as the guiding question, this paper tries to bring in the following points to analyze the emergence of Arafat as the sole leader of Palestinian National Movements and his downfall owing to the havoc caused by the Oslo Accord in 1993: Israel-Palestine conflicts and the foundation of Palestinian forces, Arafat and the birth of Palestinian revolution, Arafat and PLO leadership, Arafat's diplomatic relationship with Arab Countries, 1982 Lebanon conflict and PLO's resistance, Arafat's ideological shift, agreements and negotiations made to establish peace, the Oslo Accord and Arafat's misfortune, Arafat's role in creating and developing PNA, the second Intifada and Arafat's loss of fame and the question of Palestine after Arafat. Thus, this paper, on the one side, by looking at his development from freedom fighter to the precedent of Palestinian National Authority (PNA), critically analyzes the iconizing of his personality as the cult figure in Palestinian national movements. On the other side, it discusses his ideological positions in Palestinian issue and the two ideological strands (terrorist and freedom fighter) of his activism by people and countries throughout the world to the effect of better deducing him as the hero of Palestinian resistance movements.

The growing tension over the immigration of Jews into Palestine in large number and occupation of Palestinian lands by them eventually resulted in creating the unprecedented conflict between Arab and Israeli forces in 1948. Having been fought with huge artilleries and fatal weapons on Jewish side and only manpower on Palestinian side, the conflict finally concluded by bestowing a separate state for Jews in the land of Palestine, while exiling thousands of Palestinians into nearby Arab countries as refugees. For the first time in Palestinian history, it made Palestinians stay in the internal refugee camps modeled after concentrated camps of Nazi Germany. It has been recorded that more than 400 Palestinian villages were razed by Jewish forces and about 750000 Palestinians were forcibly uprooted from their ancestral places (Afp, 2017). While the Jewish people faced the conflict with the strong military wing Haganah (the underground militia) and two small irregular groups the Irgun and LEHI, Palestinians encountered the conflict with the support of Arab Liberation Army composed of volunteers from Palestine and neighboring Arab countries like Egypt, Jordan, Lebanon, etc. As the conflict grew more intense after the formation of the state of Israel, the United States tried to have armistice agreement between two parties based on United Nations convention 181 brought out in 1947. Finally, after many negotiations and much deliberation, the UN convention was agreed upon by letting Israel occupy some territories of Arab places in 1949.

As the Palestinian force led by Hajj Amin al-Husayni failed in protecting the Palestinian lands from the occupation of Jews and prohibiting the formation of Israel, the new wave of second generation Palestinians decided to lead the national movement. These young and resolute adults, mostly graduates, adopted new strategies of guerrilla attacks and violent 
protests to encounter Israelites. This was in contrast to the pre-Nakba (catastrophe) conflict of 1948, as the older generation leaders like al-Husayni and Ahmed Shukairy used a traditional method of patronage based leadership: "The older generation, those Arab Palestinians who occupied positions of political and social authority prior to 1948, was fully a product of the political structure of Palestine, which was based on a variety of patronage networks, and closely tied to family-oriented social hierarchies" (McCormack, 2012, p. 39). Those young adults were grouped into two factions: one was led by the icon of Palestinian resistance Yasser Arafat; the other one was led by George Habash. The former staunchly believed in guerrilla fighting and armed revolution as the only solution for Palestinian cause; whereas, the latter advocated for Arab unity before launching the attacks against Israelites. While Arafat established the political movement "Fatah" to fight for Palestinian independence, Habash founded the Arab National Movement (ANM) with the influence of prevailing Arab Nationalism to struggle for the liberation of Palestine in the 1950s.

Arafat's activism was strongly founded in Palestinian Liberation Movement, while refuting any alliance with the Arab Union from the beginning. He was of the opinion that the Arab countries supported the Palestinian cause for their own benefits, and that they annexed the important Palestinian places such as West Bank and Gaza Strip after the conflict. For this reason, he did not have any alliance with Arab National Movement and the Pan-Arabism of then Egyptian president Abdel Nasser. Arafat founded the Fatah Movement in 1959, one which was solely based on Palestinian national liberation struggle, to unite the Palestinians who lived in Arab countries as exilic people towards the Palestinian cause. He led this movement successfully until his death in 2004, often carrying out guerrilla attacks against Israeli Army. Arafat and the young Palestinians refugees who formed the Fatah Movement drew inspiration from the Nakba conflict and the narratives that came out in the aftermath. Further, they also looked at the influential works like Frantz Fanon's The Wretched of the Earth (1961) for their ideological bases rooted in the anti-colonial movements (McCormack, 2012, p. 47). The Fatah Movement under the leadership of Arafat, having carried out guerrilla attacks infrequently and unorganized manner before 1965, began launching systematic and frequent attacks against Israeli forces from 1965 onwards, leading to the 1967 - Six Days conflict.

Having been founded as the political movement, the Fatah attained the position of political party in the mid of 1960s owing to its wide-spread influence in national movement and popularity among Palestinians both inside and outside Palestine. The PLO, formed as an umbrella organization in the Palestine liberation movement in 1964 to garner the scattered small guerrilla and political groups among Palestinians, did not make a foray into the mainstream movement until the 1967 conflict. Despite Arafat's Fatah movement having carried out some guerrilla attacks before the said conflict, it could not surpass the Arab forces from taking lead in the movement. It was after the major defeat of Arab forces in the conflict that Palestinians, indeed, realized that relying on the Arab countries for their independence was futile. Not to mention, the conflict let Israeli occupy the territories such as West Bank and Gaza Strip that were previously under the control of the Arab countries. This provided a space for Fatah to lead the movement by prioritizing the armed resistance as the viable way to get back their lost lands and eliminate Israelites from the land of Palestine completely. With the considerable popularity which Fatah and its leader Arafat had among Palestinians in and out of Palestine, and with the help of guerrilla attacks carried out in the mid of 1960s, the Fatah successfully occupied the center stage of liberation struggle without much oppositions in the post-conflict period. As a result of which, Arafat became the leader of PLO in 1969.

After Arafat gaining the PLO leadership, by using his political influence, he brought the political factions such as Popular Front for the Liberation of Palestine (PFLP) and 
Democratic Front for the Liberation of Palestine (DFLP) under the aegis of PLO. These groups, as discussed earlier, before the conflict, aligned themselves with the Arab Nationalism, and thus functioned under the guidance of the Arab countries. With the inclusion of these organizations, the PLO had become the sole representative of entire Palestinians in the beginning of 1970s and the single political party to carry forward the Palestinian liberation struggle. Despite getting a huge support from Israeli occupied places of Palestine, it operated from nearby Arab countries like Jordan and Lebanon. By having guerrilla attacks, ambushing and violent protest as the major strategies of the resistance movement, the PLO nearly for two decades - 1970s and 1980s, attacked Israel ceaselessly and lost many of its fighters. In the 1970s, with the reluctant support of Jordanian king Hussein, it based the headquarters in Amman. However, after the "Black September" conflict in 1970, the PLO was forced to move to Lebanon. In Lebanon also, it established the headquarters by combating with the Lebanese army, and while allying with Muslim militias.

The Arab countries which initially belittled the PLO and Palestinian liberation movements like Fatah, began recognizing PLO as the sole body of liberation struggle in the 1970s and supported its methods in combating the Israeli forces. It was mainly made possible by the change in Arafat's stand in looking at the Arab countries from hostility to Palestinian alliance. Unlike his initial phase of activism, the 1970s witnessed Arafat's more nuanced understanding of association and diplomatic relationship with Arab countries to achieve PLO's broader objectives of self-determination and resettling the exiled Palestinians into their lands. The "Cairo Agreement" made between the PLO's president Arafat and the Lebanese army commander General Emile Bustani in 1969, for instance, is considered to be the more mature approach of Arafat, as it let the Lebanese army handover the control of 16 Palestinian refugee camps to PLO. However, as the two conflicts: 1948 and 1967 exiled two thirds of Palestinians into neighboring countries, many of them went to Lebanon for refuge. By using this sizeable population of Palestinians, Arafat and the PLO commanders tried to establish a state within Lebanon for Palestinians like they did in Jordan. While such strong presence of Palestinians and their control over some territories of Lebanon posed a threat to Lebanese government and Christian Phalangist party, the Israeli army tried its best to evacuate PLO from Lebanon by aligning with Phalangists.

The long Lebanese Civil War, began in 1975, reached its pinnacle in 1982 when Israeli army started its second round of attack in the city of Beirut, focusing mainly on the refugee camps of Palestinians. The Arab and Western media termed this unprecedented gruesome conflict as "siege of Beirut," for the Israeli army brought the entire city into its control after intense invading of two months. In these two months of severe shelling and bombarding, tens of thousands of Palestinians lost their lives and the PLO suffered from irrevocable resources and manpower. Nonetheless, Arafat, a resolute and high morale leader of Palestinian liberation struggle nearly for two decades, fervently talked about his military strength in his 1982 interview with the American journalist David Hirst: "Hirst: Are you confident you can resist? Arafat: We are waiting for them. They are welcome. We shall fight them in every street, in every place" ("Interview with Yasser Arafat," 1982, p. 283). This ceaseless bombarding on Beirut by the Israeli army led to the unforgettable Sabra and Shatila Massacre in September 1982, causing the death of over 800 innocent Palestinians. To avoid the criticism of international forums, Israel clandestinely allied with Phalangisst party in Lebanon to stage the said massacre without any hindrance in order to eliminate PLO completely from the region.

After two months of rigorous bombarding and airstrikes on Beirut and the resultant mass murder in Sabra and Shatila refugee camp located in the city, the PLO eventually left 
Lebanon and went to Tunis. Yet, as Arafat says in his interview in 1983 with Ghassan Bisharay: "But I have to tell them that they cannot harm us, though they may be able to scratch us, and despite the passing of 115 days since they began this Beqaa conspiracy, they have not hurt us. In spite of all these attempts, and since the Israeli army first bombed us on June 4, 1982, we probably can say that we are here to stay until victory" (Arafat \& Bishara, 1983, P, 4). While describing about their revolution in the same interview, Arafat says that theirs is not only based on gun to show that they are thieves and robbers, rather it lies in surgeon's scissors, farmer's hoe, worker's hammer, a Palestinian woman sewing for her children late at night and a newborn Palestinian child on Palestinian soil (Arafat \& Bishara, 1983, p. 5). The aftermath of 1982 Lebanon conflict also witnessed Arafat's stanch critique of US stand in Palestinian issue and its soft alliance with Israeli government in dealing with PLO's resistance movement (Arafat \& Bishara, 1983, p. 6). Especially, what termed to be a viable and major peace agreement proposed by USA, "The Reagan Plan" (1982) was severely criticized by Arafat by saying that it essentially denies their fundamental right of selfdetermination. (Arafat \& Bishara, 1983, p. 5)

The latter part of 1980s saw the change in Arafat's stand in Palestinian issue, he started advocating for "Two State Solution" over his political objective of "One State Solution." This surprising change in Arafat's political stand in the struggle for the liberation of Palestine was revealed in the declaration of Palestine National Council's (PNC) meeting held in 1988 in Algiers. In this historical meeting, the 1967 UN Security Council's resolution 242 was unanimously accepted, and thus recognizing the existence of Israel alongside 1967 Palestinian territory. Meanwhile, the First Intifada (uprising) erupted in Jerusalem, West Bank and Gaza among Palestinians who lived in such places, rejuvenated the declined PLO's liberation struggle after its evacuation from south Lebanon. As the Hebrew University professor Avraham Sela argues in his article published in the Israeli newspaper Haaretz, the Intifada movement significantly shifted the Palestinian struggle from outside to inside (The First Intifada: How the Arab-Israeli Conflict Was Transformed - Haaretz). The Intifada, besides creating two groups of rebellions in Palestine: common people consisted of professors, doctors, students and farmers, and the Islamic resistance movement Hamas, compelled the Israeli government to initiate the peace negotiation through the persistent violence of four years. Eventually, after much suffering and casualties, both the sides sat for peace process in what came to be called in Palestinian history "The Madrid Peace Conference in 1991," paving a viable way for the new strategy of peace negotiation for long-standing Israeli-Palestinian conflict.

The decade of 1990s acquires greater significance in Palestinian history, for the major negotiations, peace settlements and crucial political changes occurred in the struggle for independence. The 1991 Madrid Peace Conference led to the historical agreement called "The Oslo Accords" (1993) and the subsequent establishment of PNA in West Bank and Gaza Strip by the PLO. While it was agreed by both the sides that an interim state would be formed in the above mentioned places by Palestinians, the second round of Oslo Accords signed in 1995 facilitated Israel to control the territory and PLO to manage the civil and local governance. This interim arrangement, however, did not bestow a complete autonomy to PLO in forming the state. For instance, the PNA was set up at the cost of leaving out two thirds of Palestinian refugees and self-determination, which were the primary objectives of PLO until 1990. Moreover, this agreement manifested further change in Arafat's political stand, as he turned to "Binational State Solution" from his erstwhile "Two State Solution." For signing the accord and the subsequent compromise on the political objectives of Palestinian liberation struggle, Arafat was severely criticized by his own people and the staunch supporters of PLO like Edward Said, Mahmoud Darwish and Sarin Nusseibeh. This also made PLO lose many significant supporters and witness followers coming out of PLO, 
as they felt that it was a unilateral decision. Though the accord fetched him the Noble Prize for peace and revered by many countries, he could not convince his own people. Nevertheless, he unflinchingly continued his vision of creating PNA in the Palestinian territories by garnering resources and experts in law, governance and other related fields.

With the implementation of Oslo accords, Arafat attained the new responsibility of becoming the first president of PNA in 1994, besides his chairmanship of PLO. As he took charge of this challenging and ambitious responsibility of creating a new state for beleaguered Palestinians at a time when both Israel and Palestine were facing political instability and the rise of insurgence of religious fundamentalists, he had to obliterate or to be oblivious of the new wave of Islamic resistance movement led by Hamas as a deterrence of upcoming new state. In addition to this, he had to also build an infrastructure for the new state in all levels, for the given territories were completely damaged and ruined in the perpetual conflict. It is evident in his interview to ABA Journal in 1994:

Actually, there are many problems, not one problem. Under the occupation, all our infrastructure has been completely destroyed. They are leaving nothing behind them. From the water, which we have a problem with in the Gaza Strip; from the electricity, the communications to the hospitals, schools, universities; the drainage problems; social affairs; municipalities-especially in Gaza where life has arrived down to the red line of starvation. And this is according to the United Nations reports. And the very bad economic situation in the West Bank. How we can bring about a normal life to the people, to have a normal life, it is a really important target after this long occupation. (Hemgstler \& Fricker, 1994, p. 47)

This demonstrates the kind of basic infrastructure ranging from water to educational institutions that Arafat had to build in the newly formed state for Palestinians without any economic backing. Furthermore, it has also embodied his dynamic leadership quality and the multifaceted abilities that he possessed throughout his activism.

The creation of interim state for Palestinians and the resultant peace process facilitated by the Oslo Accords did not last for longtime, for the Second Intifada broke out in 2000 foiled its function and collapsed the prevailing peace agreement between Israel and PLO. On the other hand, it was also believed that growing disappointment and frustration over the low economic development and inadequate infrastructural facilities among Palestinians who lived in PNA governed territories also attributed to the unpredicted emergence of Second Intifada. Arafat, being the president of PNA, could not do anything to control the outbreak of abrupt violence and the subsequent commotion ensued from the Intifada movement, for PLO played a meager role in the movement. Like the First Intifada, the second one was also carried forward by Hamas and other religious factions, who could not be easily controlled by the Israeli Army (The Second Intifada). Nevertheless, the Israeli government and the United States accused Arafat for assisting such religious factions to involve in terrorist activities. As a result, notwithstanding the prevailing of truce facilitated by Saudi Arabia, the Israeli army severely attacked Ramallah and besieged Arafat's headquarters in 2003 (The Second Intifada | News News | Al Jazeera). This besiegement of Arafat by the Israeli army persisted till his death in 2004. It also exemplifies Arafat's loss of fame among his own people, as they did not protect when the Israeli army was trying to confine him. As discussed earlier, the signing of Oslo Accords and the compromise made therein had discredited his towering image among Palestinians. Thus, towards the end of his life, Arafat was disregarded by his own people for whom he fought for five decades and faced countless life threats. Faced with the criticism of being terrorist and traitor by Israel and US, 
and some faction of Palestinians respectively, he was compelled to clarify his stand on the one side, on the other side, he realized his dream state for Palestinians in peril of once again controlled by Israeli government.

As the signing of Oslo Accords brought Arafat's stature down and made him lose his reputation among his followers and people in the latter half of 1990s, the kind of guerrilla movement that he led through his political party Fatah and the series of peace initiatives which he started to achieve his objectives of establishing a separate state for homeless Palestinians have, indeed, got him prominent place in the history of Palestinian liberation struggle. When he died, he left behind a rich legacy of resistance and peace negotiation, the two distinct strategies of Palestinian national movement, for his younger generation to follow. His life and the unwavering political movement that he led are the embodiment of these two strategies being tested with many casualties and of course with severe criticisms leveled against his stands. As Gary A. Hengstler and Richard L. Fricker(1994) state in their interview with Arafat about the indubitable reputation that he continues to hold, despite various allegations: "To some he will always be a terrorist, for others he is a statesman. But in the new world realities, Yasser Arafat is still the most high-profile representative of a people without a homeland or a government" (46). It is, certainly, not an exaggeration to say that Arafat through his vibrant political movement fraught with the dream of retrieving lost homeland has kept the Palestinian identity alive. To such extent, he brought the plight of Palestinian refugees to the world forums and argued for their fundamental right to return to their occupied places. When he was given an opportunity to select among identity, territory and power, he unquestionably chose territory, for it entails identity and the power to have self-determination.

Besides mapping out the crucial struggles and the movement that Arafat led for the liberation of Palestine, this paper has discussed the evolving of his heroic figure in the longstanding resistance movements against the occupation of lands by Israelites. By tracing the resistance movement from the time of pre-Nakba period onwards, it has tried to locate the role of Arafat in the broader socio-political movements led by Palestinians and Arabs, and explicated how he played an indispensable part in the various conflicts occurred in the second half of twentieth century. His five decades of vibrant activism and resolute leadership in the Palestinian national movement have been analyzed by keeping in mind the following historical occurrences and the varied political strands: Israel-Palestine conflicts and the foundation of Palestinian forces, Arafat and the birth of Palestinian revolution, Arafat and PLO leadership, Arafat's diplomatic relationship with Arab Countries, 1982 Lebanon conflict and PLO's resistance, Arafat's ideological shift, Agreements and negotiations made to establish peace, The Oslo Accord and Arafat's misfortune, Arafat's role in creating and developing PNA, The second Intifada and Arafat's loss of fame and the question of Palestine after Arafat. Through the discussion of these significant incidents in the history of Palestinian liberation struggle, it has been inferred that Arafat streamlined the scattered political and guerrilla factions, and organized a concerted movement to counter the mighty Israeli army. Further, this discussion has also demonstrated how the political climate prevailed in the 1980s and 1990s changed Arafat's political stand from one state solution to bi-national state solution, and the two distinct ways (terrorist and freedom fighter) in which he has been looked at by Israel, US and Arab countries. In general, notwithstanding these criticisms, as Sukumar Muralidharan (2004) says in his article: "Till his death, Arafat was a visible reminder to the world that the struggle against colonialism remained incomplete as long as the Palestinians remain a people without a state" (5089). 


\section{References}

Afp. (2017, October 31). The Israel-Palestine conflict-100 years of history. The Hindu. https://www.thehindu.com/news/international/the-israel-palestine-conflict-100-yearsof-history/article19954348.ece

Arafat, Y., \& Bishara, G. (1983). Yasser Arafat. Journal of Palestine Studies, 13(1), pp. 3-8. https://doi.org/10.2307/2536922

Hengstler, G. A., \& Fricker, R. L. (1994). Yasser Arafat: My Vision. ABA Journal, 80(2), pp. 46-49.

Interview with Yasser Arafat. (1982). Journal of Palestine Studies, 11/12, pp. 282-284. https://doi.org/10.2307/2538381

McCormack, N. E. (2012). The sociopolitical foundations of Palestinian Resistance, 19481970 [Thesis]. https://repositories.lib.utexas.edu/handle/2152/ETD-UT-2012-05-5774

Muralidharan, S. (2004). Yasser Arafat: Fighter against Implacable Odds. Economic and Political Weekly, 39(48), pp. 5088-5091.

The first intifada: How the Arab-Israeli conflict was transformed-Haaretz ComHaaretz.com. (n.d.). https://www.haaretz.com/.premium-first-intifada-a-watershedmoment- 1.5272288

The second Intifada $\mid$ News News $\mid$ Al Jazeera. (n.d.). https://www.aljazeera.com/news/2003/12/4/the-second-intifada

\section{Bio-note}

Dr. Boopathi P, is an Assistant Professor in the Department of English Studies, School of Social Sciences and Humanities, Central University of Tamil Nadu. His research interests include Disability Studies, Palestine and West Asian Literature, Postcolonial and Resistance Literature, and Life Writing Studies. For his Doctoral Research, completed at EFL University, Hyderabad, he studied the identity construction of Palestinians in the life narratives written by Palestinian refugees. Prior to his appointment at CUTN, he taught at Aligarh Muslim University for three years. He has published articles in journals and edited books that are of international repute and presented research papers in conferences both inside and outside India in his areas of research. His research works have been published by renowned international publishers like Peter Lang, Routledge and Routledge Journal of Life Writing. He is one of very few scholars in the area of Disability Studies in India to introduce a specialized course titled "Disability Studies and Literature" to Master students of English Literature. He is a member on the Editorial Review Board of International Journal of Whole Schooling published by University of Michigan Press.

Email Id: pboopathi@cutn.ac.in 